\title{
Influence of water availability and temperature on estimates of microbial extracellular enzyme activity
}

\author{
Enrique J Gomez ${ }^{1}$, Jose A Delgado ${ }^{1}$, Juan M Gonzalez ${ }^{\text {Corresp. } 1}$ \\ ${ }^{1}$ Instituto de Recursos Naturales y Agrobiología, Consejo Superior de Investigaciones Científicas, IRNAS-CSIC, Sevilla, Spain \\ Corresponding Author: Juan M Gonzalez \\ Email address: jmgrau@irnase.csic.es
}

Soils are highly heterogeneous and support highly diverse microbial communities. Microbial extracellular enzymes breakdown complex polymers into small assimilable molecules representing the limiting step of soil organic matter mineralization. This process occurs on to soil particles although currently it is typically estimated in laboratory aqueous solutions. Herein, estimates of microbial extracellular enzyme activity were obtained over a broad range of temperatures and water availabilities frequently observed at soil upper layers. A Pseudomonas strain presented optimum extracellular enzyme activities at high water activity whereas a desiccation resistant bacterium (Deinococcus) and a soil thermophilic isolate (Parageobacillus) showed optimum extracellular enzyme activity under dried (i.e., water activities ranging 0.5-0.8) rather that wet conditions. Different unamended soils presented a distinctive response of extracellular enzyme activity as a function of temperature and water availability. This study presents a procedure to obtain realistic estimates of microbial extracellular enzyme activity under natural soil conditions of extreme water availability and temperature. Improving estimates of microbial extracellular enzyme activity contribute to better understand the role of microorganisms in soils. 
1 Influence of water availability and temperature on 2 estimates of microbial extracellular enzyme activity

3

4

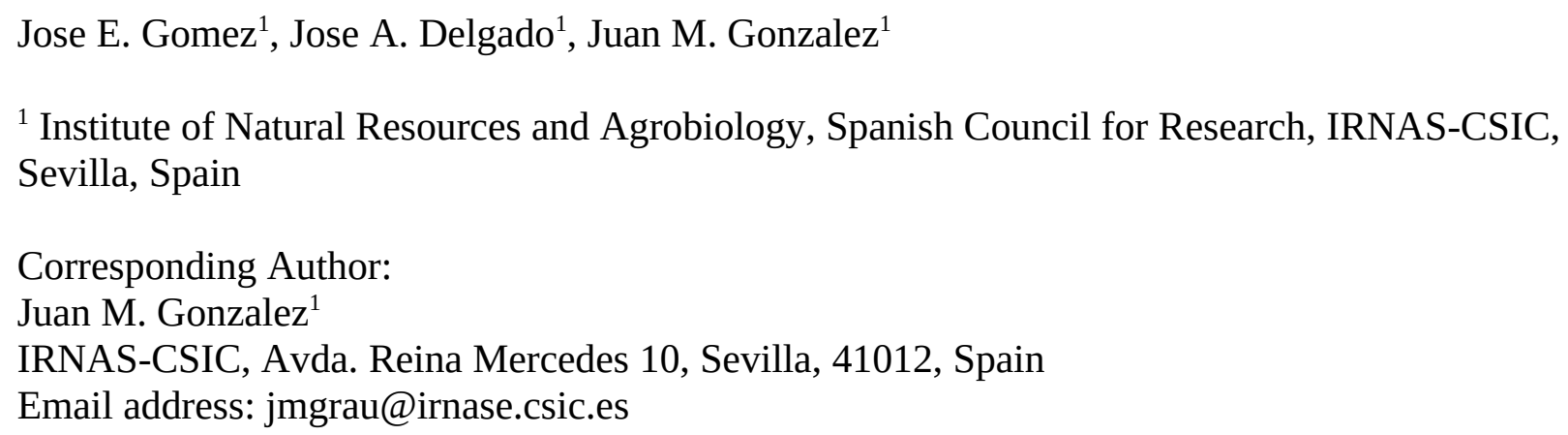

\section{Abstract}

Soils are highly heterogeneous and support highly diverse microbial communities. Microbial extracellular enzymes breakdown complex polymers into small assimilable molecules representing the limiting step of soil organic matter mineralization. While this process occurs on soil particles, currently it is typically estimated in laboratory aqueous solutions. Herein, estimates of microbial extracellular enzyme activity were obtained over a broad range of temperatures and water availabilities frequently observed at soil upper layers. A Pseudomonas strain presented optimum extracellular enzyme activities at high water activity whereas a desiccation resistant bacterium (Deinococcus) and a soil thermophilic isolate (Parageobacillus) showed optimum extracellular enzyme activity under dry (i.e., water activities ranging 0.5-0.8) rather that wet conditions. Different unamended soils presented a distinctive response of extracellular enzyme activity as a function of temperature and water availability. This study presents a procedure to obtain realistic estimates of microbial extracellular enzyme activity under natural soil conditions of extremely low water availability and temperature. These improved estimates of microbial extracellular enzyme activity will contribute to better understand the role of microorganisms in soils.

\section{Introduction}

Soil microorganisms play a critical role in the cycling of elements maintaining soil health. However, little is known about how microbial activity is influenced by soil features and the consequences of these interactions on local and global scales. This is due, for example, to the complexity of the soil environment and the huge functional and taxonomical diversity observed in the microbial world (Lupani et al., 2017; Whitman et al., 1998) which are poorly understood (Meyer et al., 2018).

Soil biogeochemical cycling of elements is governed to a large extent by the activity of microorganisms (Conant et al., 2011). Nutrients and their availability, including organic matter, are the result of a balance between the biotic (their use as source for growth and maintenance of organisms, both microbes and macro-organisms) and abiotic (including complex chemical interactions) components. In this respect, the stock of carbon in soil is larger than the atmospheric stock and carbon accumulation and mineralization represent major factors 
46 affecting the global soil-atmosphere carbon balance which influences global warming (Davidson

47 \& Janssens, 2006; IPCC, 2014).

48 Soil organic carbon decomposition is mainly performed by microorganisms (Conant et al., 2011;

49 Whitman et al., 1998). To process soil polymers and high molecular weight compounds,

50 microorganisms need to break them down into monomers or assimilable, smaller subunits that

51 can be taken up for further metabolic processing (Asmar et al., 1994; Madigan et al., 2003). This

52 first step of decomposition is carried out by microbial extracellular enzymes and their production

53 is regulated by the microbial communities as a function of the availability of different organic

54 substrates (Velasco-Ayuso et al., 2011) and the environment (Santana \& Gonzalez, 2015). These

55 extracellular enzymes represent the rate-limiting step for the biological consumption and

56 mineralization of soil organic matter (Chrost, 1992; Conant et al., 2011; Gonzalez et al., 2015)

57 and their activities are expected to be ruled by environmental conditions (e.i., temperature,

58 moisture, $\mathrm{pH}$ ).

59 Upper soil layers are exposed to broad variations of environmental conditions, such as

60 temperature and moisture. For instance, arid, semi-arid and desert soils frequently reach high

61 temperatures. Some reports mentioned common temperatures in the range of $50^{\circ} \mathrm{C}-70^{\circ} \mathrm{C}$ in

62 temperate soils from medium latitudes (Gonzalez et al., 2015) and values above $90^{\circ} \mathrm{C}$ in deserts

63 (McCalley \& Sparks, 2009). For example, soils from Northern and Southern Spain are exposed to

64 clearly different climate conditions (i.e., Atlantic vs. Mediterranean climates, respectively).

65 Northern Spain is rainy with mild temperatures while Southern Spain show higher temperature

66 and dry periods with a more pronounced risk of aridity. Besides, the importance and ubiquity of

67 thermophilic microorganisms in soils have been reported (Marchant et al., 2002; Portillo et al.,

68 2012) including cold areas at high latitudes (Wong et al., 2015). Recently, the effect of high

69

70

71 temperatures has been associated to a decrease of soil organic content (Biederman et al., 2016; Bragazza et al., 2016; Cheng et al., 2017; Santana \& Gonzalez, 2015) and so activity of thermophilic microorganisms and climate change appear to be linked (Santana \& Gonzalez, 2015). About the influence of wet/drying periods, there are numerous reports showing an enhancement of microbial and enzymatic activities in soils after rain or during wetting cycles in contrast to lower activities during dried intervals (Conant et al. 2011; Manzoni et al., 2012). Current knowledge suggests the existence of highly dynamic microbial communities and extracellular enzyme activities in soils although the detailed effects of temperature and water availability on microorganisms and their extracellular enzymes are poorly understood (Conant et al., 2011; Gonzalez et al. 2015; Manzoni et al., 2012; Santana \& Gonzalez, 2015; Wallenstein \& Weintraub, 2008). High temperatures tend to be accompanied with low water content in soils (Biederman et al., 2016). However, most soil enzymatic assays to measure enzyme activities are performed in solution at or below $30^{\circ} \mathrm{C}$ (Craine et al., 2010; Fierer et al., 2006; Townsend et al., 1992) which is not necessarily representative of the actual conditions found in soil upper layers and, above all, those with scarce plant coverage during the summer season. Currently, there is interest to approximate field conditions to perform extracellular enzyme assays in soil samples (Wallenstein \& Weintraub, 2008). For instance, peaks of maximum enzymatic activity have been recently observed at high temperatures in all soil samples (Gonzalez et al. 2015) from a wide range of latitudes and soil types. Besides, enzymatic assays to approach hydrolytic enzyme activity in soils are typically carried out in solution. Unlike it, upper soil layers can get dry. Decreasing water availability in soils results in desiccation events leading to major changes in the microbial communities and certainly in their enzyme activities catalysing soil organic matter decomposition (Biederman et al., 2016; Cheng et al., 2017; Conant et al., 2011; Tecon \& Or, 2017). The combined effects of high temperatures and low water availability on soil microbial extracellular enzyme activity remain to be understood both for soil mesophilic and thermophilic bacteria. 
95

96

97

98

99

100

101

102

103

104

105

106

107

108

109

110

111

112

113

114

115

116

117

118

119

120

121

122

123

124

125

126

127

128

129

130

131

132

133

134

135

136

137

138

139

140

141

142

143

Water availability is generally measured through the parameter water activity ( $\left.a_{w}\right)$ (Grant, 2004). Water activity represents the water available for microorganisms and it is defined as the partial vapor pressure of water in a sample divided by the partial vapor pressure of pure water. The $\mathrm{a}_{\mathrm{w}}$ can get values from 1 (in a water saturated sample) to a theoretical value of 0 (in a sample with no available water). A few attempts have been reported in the laboratory to analyze microbial enzymatic activity and water availability (Borowik \& Wyszkowska, 2016; Spark \& Firestone, 1995). Most studies on this issue have been carried out on the industrial field (Lyer and Ananthanavaran, 2008; Soares et al., 2003; Torres and Castro, 2004). It is assumed that while the active center conserves water above a minimum threshold, enzyme activity continues but below that level it will be drastically reduced. Also, maximum activity might not necessarily occur at excess of water. Generally, the procedures for these measurements involve the use of salts, sugars and/or chemicals (i.e., organic solvents) to control water activity during experimental analyses over relatively long time periods (Hudson et al. 2005; Maurice et al., 2011). However, the addition of most of these water activity-limiting chemical mixtures might alter, or might not be representative of, the behavior of microorganisms and their enzymes in soils. For example, supplementation with salts or organic solvents can affect protein structure and so enzyme and microbial activities (Borowik \& Wyszkowska, 2016; Hudson et al., 2005; Lee \& Dordick, 2002;

Oren, 2010). Soil drying processes are not necessarily homogenous among soil particles and their cavities can form heterogenous microniches (Tecon \& Or, 2017; Vos et al., 2013).

The influence of water availability (under low water activity conditions) on natural soil microorganisms and their EEA remains to be clearly understood. Due to the non-linear relationship between water activity and moisture (Mathlouthi 2001), soil moisture (by weight or volume) values generally reported correspond to measurements at high water availability values (moisture $\geq 10 \%$ generally corresponds to $a_{w}$ above 0.8 ) thus excluding information from low water availability conditions from experimentation (Mathlouthi 2001; Grant 2004; Steinweg et al. 2012; Moxley et al. 2019). Similarly, enzyme activity in soil has been measured at relatively elevated water potential values (generally >-4 Mpa)(Stark \& Firestone 1995; Steinweg et al. 2012) also representing high water activity values $\left(a_{w}>0.9\right)$. Thus, the ideal approach to assess enzyme activity in soils should avoid or minimize the addition of supplements, be performed within a reasonable short timeframe, and approach low water activity conditions.

Currently, soil extracellular enzyme activities are mainly determined in laboratory aqueous solutions. However, soils are highly heterogeneous environments formed by a conglomerate of particles where water is frequently limited due to the meteorological conditions directly affecting upper soil layers. Drying soils have been reported to decrease or even completely suppress enzyme activity (Allison \& Treseder, 2008; Duran \& Esposito, 2000). Thus, it is required to approach microbial extracellular enzyme activity estimates with more realistic procedures in order to evaluate microbial extracellular enzyme activity in soils under a broad range of temperature and water availability conditions.

This study aims (i) to propose a new method to estimate microbial extracellular enzyme activity at different temperatures and water activities within the range of values detected in some soils (e.g., including arid systems); (ii) to gain information of the behavior of extracellular enzyme activities from specific bacteria in sterilized soils so that we can understand the influence of temperature and water availability on their capacity to hydrolyze complex organic nutrients; and (iii) to compare the activities of extracellular enzymes from two Spanish soils exposed to different environmental conditions emphasizing the specific properties of soils exposed to aridity.

\section{Materials \& Methods}

\section{Experimental design and sampling sites}

Peer] reviewing PDF | (2020:08:52457:3:0:NEW 25 Jan 2021) 
144 Extracellular enzyme activity was determined applying an assay protocol (see below) designed to 145 reproduce the potential conditions of temperature and dryness that can be found at the upper

146 layers of typical soils. Two temperatures, $20^{\circ} \mathrm{C}$ and $60^{\circ} \mathrm{C}$, were selected which represented 147 common conditions of the extracellular enzyme activity from mesophilic (Fierer et al., 2006;

148 Townsend et al., 1992) and thermophilic (Gonzalez et al., 2015) microorganisms. Water 149 availability was determined by measuring water activity $\left(\mathrm{a}_{\mathrm{w}}\right)$ using a Rotronic water activity 150 probe HC2-AW (Rotronic AG, Bassersdorf, Switzerland) at the incubation temperature. 151 Extracellular enzyme activity assays were carried out over different water activities, decreasing 152 values from 1 down to the water activity resulting in zero or near-zero enzyme activity.

153

Two types of experiments were carried out. Measurements using either unsupplemented natural soils or sterilized soils supplemented with bacterial cultures were analyzed. In order to obtain an image of the behavior of the enzymes from specific bacteria, we tested the extracellular enzymatic activity of three bacterial species isolated from soils: Pseudomonas aeruginosa, Deinococcus radiodurans and Parageobacillus thermoglucosidasius. Table 1 lists the strains used in this study. Bacterial cultures were grown in nutrient broth (Cat. No. 234000; BD Difco, Franklin Lakes, NJ, USA) at their optimum growth temperature (Table 1). Bacterial cells from these species at late exponential growth phase were supplemented to sterilized soil samples from a Southern Spain soil (see below) as a support to simulate potential soil conditions of different water content during the enzyme assays. The amended soil was previously sterilized by autoclaving at $121^{\circ} \mathrm{C}$ for 30 min during five consecutive days which removed all detectable enzyme activity in these aliquots.

The assays carried out on natural soil samples were processed unsupplemented and without treatments. The soil samples were collected from distant locations and corresponded to a sandy loam soil (Coria del Rio, Sevilla, Southern Spain; $37^{\circ} 17.027^{\prime}$ N, 006 3.973’ W; Dry summer, Mediterranean climate [Csa]) and a silt soil (Benasque, Huesca, Northern Spain; $42^{\circ} 40.922^{\prime}$ N $000^{\circ} 38.108$ ' E; Oceanic, Northern Europe climate [Cfb])(Table 2). These two soils were selected as examples of soils from different climates (humid vs. dry, cold vs. hot) to compare the influence on extracellular enzyme activity as a function of temperature and water activity. It is important to underline that the temperature and water activity to what soil microorganisms and their enzymes are exposed would induce a broad range of responses (Alster et al., 2018).

\section{Enzyme assays}

Most assays to evaluate the microbial extracellular enzyme activity in different environments are performed in solution. Unlike previous studies, we compared the activity determined in solution and following the procedure detailed below which accounts for environmental factors because they are carried out on the soil particles and at a specific water activity and temperature.

Extracellular glucosidase, protease and phosphatase activities were assayed as examples of extracellular enzyme activity in soils and represent activities commonly assayed in environmental enzyme activity surveys. These enzymes represent key steps of the process of depolymerization of high-molecular weight organic matter in soils in relationship to the $C$ biogeochemical cycle and, specifically the protease and phosphatase, to the $\mathrm{N}$ and $\mathrm{P}$ cycles, respectively. Reactions were buffered by phosphate buffer $(0.2 \mathrm{M}, \mathrm{pH}$ 7) for protease and glucosidase assays, and PIPES buffer (2 mM; piperazine-N,N'-bis[2-ethanesulfonic acid]; $\mathrm{pH} 7$ ) for the phosphatase assay. Buffer solutions were adjusted for $\mathrm{pH}$ at the temperature to be used. Enzyme assays were based on the use of the fluorogenic substrates L-leucine-7-amido-4-methylcoumarin hydrochloride (AMC) for protease activity, Methylumbelliferyl $\beta$-glucopyranoside (MUG) for glucosidase 
193

194

195

196

197

198

199

200

201

202

203

204

205

206

207

208

209

210

211

212

213

214

215

216

217

218

219

220

221

222

223

224

225

226

227

228

229

230

231

232

233

234

235

236

237

238

239

240 activity and Methylumbelliferyl phosphate (MUP) for phosphatase activity. These substrates showed stability under the assayed temperature conditions as they have been previously evaluated up to $100^{\circ} \mathrm{C}$ (Gonzalez et al., 2015). Figure 1 shows a scheme of the assays comparing a standard, in solution assay and the newly proposed assay on soil samples which allows the evaluation of dryness on soil extracellular enzyme activities.

\section{Enzyme assays under dried conditions}

Enzymatic assays (Figure 1) were performed by adding a buffered solution containing the corresponding fluorogenic substrate $(0.1 \mathrm{mM}$, final concentration; AMC, MUG and MUP) (Gonzalez et al., 2015) to natural soil (2 mg aliquots) or the sterilized soil supplemented with bacterial species. Until this point samples and solutions were maintained on ice and once the fluorogenic substrates were added, the soil mixtures were frozen at $-80^{\circ} \mathrm{C}$ to minimize substrate degradation and modification of sample conditions during handling. Samples aimed to perform enzyme activity measurements at reduced water activities aliquots were freeze dried to reduce the water content in the soil mixture and reach the required water activity. The final water activity was determined as detailed above using a Rotronic water activity probe. Samples were only freeze-dried a single period and those at a water activity close to the required water content were used for the assay. If the resulting water activity at a given soil subsample was distant from the expected value that subsample was not processed further. Reactions at different temperatures and water activities were carried out in triplicate. Once the required water activity is obtained, the aliquots were incubated in a sealed container at the required temperatures $\left(20^{\circ} \mathrm{C}\right.$ or $\left.60^{\circ} \mathrm{C}\right)$ for different time periods. Different aliquots were placed in different tubes so that for each time point three replicates were extracted from incubation. Incubation times were below $10 \mathrm{~min}$ because around this time the kinetic curve leveled-off. That time period was sufficient to estimate the linear slope of fluorescence versus incubation time in the studied cases. The enzyme assays for natural samples were incubated at $20^{\circ} \mathrm{C}$ and $60^{\circ} \mathrm{C}$. Enzyme assays for bacterial cultures were incubated at the strain optimum growth temperature. Time zero was considered when the reaction reached the desired incubation temperature. After the incubation period, the reactions were stopped by adding ethanol (Stemmer, 2004) and the pH was adjusted with ice-cold glycine$\mathrm{NaOH}(0.1 \mathrm{M} ; \mathrm{pH} 11)$ to maximize the fluorescence signal while preserving the undigested fluorogenic substrate and the fluorescent product. The stopped reaction mixture was vortexed and the solution was cleared from soil particles by centrifugation at $5000 \mathrm{x}$ g for $5 \mathrm{~min}\left(4^{\circ} \mathrm{C}\right)$. Fluorescent measurements were carried out in an Omega fluorometer (BMG LabTech GmbH, Ortenberg, Germany) using the filter sets recommended by the manufacturer (excitation $355 \mathrm{~nm}$; emission $460 \mathrm{~nm}$ ). The rate of enzyme activity was estimated by linear regression (Model I, only $\mathrm{Y}$ variable is subject to error) (Sokal and Rohlf, 2012) as the slope of fluorescence versus incubation time during the linear portion of the curve. Correlation and regression analysis (Model II, both variables are subject to error) between the results from assays following the above protocol and those performed by the classic, in-solution method (see below) where performed according to Sokal and Rohlf (2012).

\section{In-solution enzyme assays}

As a reference, enzymatic assays were also performed following the standard procedure for the estimation of extracellular enzyme activity in soils (Wallenstein \& Weintraub, 2008). To allow a comparative analysis, in-solution assays followed the protocol described above with natural soils samples but omitting the water reduction step by freeze-drying (Figure 1).

\section{Results}


In this study, we propose a novel assay for the determination of extracellular enzyme activity at reduced water activities and different temperatures which are conditions typically encountered at upper soil layers. The required water activities are obtained by freeze drying the reactions which

246 efficiently removed a fraction of the water contained in the reactions. It is important to consider that, in order to minimize the activity of enzymes on the fluorogenic substrates, the reaction mixtures must be frozen. This is also a necessary step in the freeze drying process. Once the required water activity of a reaction mixture is obtained, the incubation reaction will start just when the reaction reaches the required temperature. Time zero aliquots will be the initial fluorescence reading which accounts for potential minimum degradation of fluorogenic substrates

252

253 previous to the incubation period. Readings from later time periods showed an increase over time until a plateau of maximum fluorescence yield is reached at approximately 10 min incubation. Enzyme activity rates versus substrate concentration estimated by using the proposed procedure followed Michaelis-Menten kinetics (Figure 2).

The proposed procedure provided data equivalent to those obtained by assays in solution (Figure 3). The extracellular enzyme activity measurements from two different soil types resulted in a significant relationship (correlation coefficient $\mathrm{r}=0.90 ; \mathrm{n}=12 ; \mathrm{P}<0.001$ ). The $95 \%$ confidence limit of the estimated slope included the 1:1 reference line showing that both assays provided similar results when compared at $\mathrm{a}_{\mathrm{w}} 1$. At the highest measured enzyme activities, the results tended to the largest differences between the in-solution and solid assays, showing slightly higher values in solution. This trend would suggest that substrate diffusion (Tecon \& Or, 2017) could start to become an issue under high enzyme activity conditions in soils. At $\mathrm{a}_{\mathrm{w}}<1$ comparisons become impossible because the in-solution assay can not be performed (i.e., without the addition of organic solvents or salts that could negatively affect the activity of soil enzymes). Results of fitting a Gaussian curve (Normal distribution) to replicates from in-solution and solid assays suggested a larger variability (2-fold) of the solid assays likely due to the heterogeneity typically found in soil particles versus the homogeneity of solutions.

\section{Extracellular enzyme activity by bacterial isolates}

To evaluate the behavior of extracellular enzymes in soils we first tested three bacterial cultures to approach how these enzymes could function under a range of water activity conditions commonly observed at upper soil layers. The results of specific bacterial species should be a necessary step towards attempting to understand the behavior of extracellular enzyme activities in soils. Figure 4 shows the results obtained from the extracellular enzyme activities measured for three cultured species at different water activity values. For instance, the proteobacterium $P$. aeruginosa, a well studied mesophilic strain, showed maximum extracellular enzyme activity at water activity equal to 1 . When the water activity was reduced, the extracellular enzyme activity of this bacterial species rapidly decreased so that glucosidase and phosphatase activities dropped to undetectable rates at water activity values of 0.8 (Figure 4 ). When the water activity was reduced to 0.8 , the protease activity for $P$. aeruginosa remained around $80 \%$ (Figure $4 \mathrm{a}$ and $4 \mathrm{~b}$ ) and sharply decreased at lower $\mathrm{a}_{\mathrm{w}}$ values. Similar behavior was observed for a laboratory strain, Escherichia coli (K12) (data not shown).

D. radiodurans is a model bacterium for the study of desiccation resistance (Potts, 1994; Slade \& Radman, 2011). When the response of extracellular enzyme activity by $D$. radiodurans was evaluated as a function of water activity, the results were slightly different depending on which type of enzyme was analyzed (Figure 4c). D. radiodurans glucosidase activity decreased 
290

291

292

293

294

295

296

297

298

299

300

301

302

303

304

305

306

307

308

309

310

311

312

313

314

315

316

317

318

319

320

321

322

323

324

325

326

327

328

329

330

331

332

333

334

335

336

337

338

progressively at decreasing water activity. However, its phosphatase activity was mantained constant in the range of water activities from 0.55 to 1 although $D$. radiodurans phosphatase activity drastically dropped to zero at $\mathrm{a}_{\mathrm{w}} 0.4$. The protease activity of this bacterium showed a peak of maximum activity at $\mathrm{a}_{\mathrm{w}} 0.55$ and for $\mathrm{a}_{\mathrm{w}} 0.35$ its activity was sharply reduced to undetectable levels (Figure 4 ). Interestingly, $D$. radiodurans protease activity under wet conditions $\left(a_{w}=1\right)$ showed a poor activity rate (30\% of its maximum at $\left.a_{w} 0.55\right)$.

An example of a thermophilic soil isolate is Parageobacillus thermoglucosidasius which is a common representative of the thermophilic Firmicutes found in soils (Santana \& Gonzalez, 2015). For this isolate, glucosidase and protease activities showed peaks of optimum activity at $\mathrm{a}_{\mathrm{w}}$ 0.8 (Figure 4 ) decreasing at lower water activities. Its activity was relatively low (20\%-30\% of maximum values) under wet conditions $\left(\mathrm{a}_{\mathrm{w}}=1\right)$. The $P$. thermoglucosidasius isolate phosphatase activity showed moderate enzymatic activity at high $\mathrm{a}_{\mathrm{w}}$ values (above 0.7 ) and a similar model to its other extracellular enzymes. Nevertheless, its phosphatase activity was observed at $\mathrm{a}_{\mathrm{w}} 0.6$ and sharply decreased to undetectable values at $\mathrm{a}_{\mathrm{w}} 0.5$ (Figure 4).

\section{Extracellular enzyme activity in natural soil samples}

Soil extracellular enzyme activities were assayed to quantify the enzyme activities of mesophilic $\left(20^{\circ} \mathrm{C}\right)$ and thermophilic $\left(60^{\circ} \mathrm{C}\right)$ microorganisms over a broad range of water activities (from dryness to wet conditions). Experimental estimations of extracellular enzyme activity from natural soil samples showed different responses depending on both temperature and water activity (Figure 5). For a soil frequently exposed to high temperatures (Southern Spain soil), the optimum values of enzyme activity at the mesophilic condition were observed at high $\mathrm{a}_{\mathrm{w}}$ values (at 0.95 ). This soil at the thermophilic condition showed optimum enzyme activity values at $a_{w}$ 0.65 (Figure 5), with reduced activities at $\mathrm{a}_{\mathrm{w}} 1$ and undetectable activities at very low values of $\mathrm{a}_{\mathrm{w}}$ $(<0.3-0.4)$.

When analyzing the results of extracellular enzyme activities at different temperatures and water activities for a soil rarely exposed to high temperatures and in a wet environment (Northern Spain), the results were quite different (Figure 5). In this soil, the optimum extracellular enzyme activities (both for mesophilic and thermophilic acitivities) were observed at high $\mathrm{a}_{\mathrm{w}}$ (around 1) and the enzyme activity decreased when reducing water activities. These results showed a clear differentiation of the studied soils according to their extracellular enzyme activity which is strongly dependent on temperature and water activity.

\section{Discussion}

Temperature and water availability are two major environmental factors directly affecting microbial community structure and its functioning. However, our understanding of the effect of temperature and water availability on the activity of extracellular enzymes in the environment is very limited (Gonzalez et al., 2015; Wallenstein \& Weintraub, 2008) and this represents a serious handicap to evaluate future models and potential scenarios of $\mathrm{C}$ flow at local and global levels (Santana \& Gonzalez, 2015). Previous publications (Gonzalez et al., 2015; Wallenstein \& Weintraub, 2008) have emphasized the importance of temperature on enzyme activity and the fact that soil enzyme activities are typically only measured at a single temperature and often far from the field site temperature. Besides, previous estimates of EEA correspond exclusively to relatively high water availability (Stark \& Firestone 1995; Mathlouthi 2001; Steinweg et al. 2012; Borowik \& Wyszkowska 2016) and desiccation conditions, particularly in arid ecosystems, remain to be studied (Moxley et al., 2019). The present study contributes to our understanding of the microbial extracellular enzyme activity as a function of temperature and water activity by

Peer] reviewing PDF | (2020:08:52457:3:0:NEW 25 Jan 2021) 
339

340

341

342

343

344

345

346

347

348

349

350

351

352

353

354

355

356

357

358

359

360

361

362

363

364

365

366

367

368

369

370

371

372

373

374

375

376

377

378

379

380

381

382

383

384

385

386

387 proposing a novel methodological strategy approaching enzyme activity under the effect of these environmental parameters (temperature and water availability) in a highly heterogenous particulate support media (i.e., soil).

The proposed procedure consists on reducing the water availability by freeze-drying the studied samples so that the enzyme activity can be evaluated under the desired conditions of water activity. Although freeze-drying processes have been reported to potentially cause moderate loss of activity to some enzymes (Valaskova and Baldrian, 2005), our results showed minimum effects on soil extracellular enzyme activity at high water activity values in solution and solid assays (Figure 3). Adapting the protocols of enzyme assays to this important step allows to approach realistic measurements of the role of extracellular enzymes under these, so far, scarcely studied conditions. Besides, variations of temperature and water content are frequently observed at the upper layers of natural soils. Using this simple protocol that gap can be filled to understand how the extracellular enzymes function during the periods that are exposed to high temperature and low water availability. So far, estimations performed in the environment have been commonly carried out in solution which provides a potential measure of extracellular enzyme activity under wet, high water content, conditions. Nevertheless, upper soil layers can frequently get hot and dry mostly in arid systems.

When measuring microbial extracellular enzyme activities in soils one should be aware that soils are highly heterogeneous, particulate environments. In this type of media, proteins, such as extracellular enzymes, tend to adher to soil particles (Kolman et al., 2014). Enzyme adsorption to particles is an immobilization process involving diverse physical interactions which could result in a reduction of enzyme activity (Allison \& Treseder, 2008; Datta et al., 2017; Rodrigues et al., 2013) as a consequence of possible conformational changes in the enzymes. Besides, it is well known that immobilized enzymes are subject to substrate diffusion limitations (Datta et al., 2017; Duran \& Esposito, 2000; Tecon \& Or, 2017). These issues could also occur under certain conditions in soils resulting in changes of enzyme assay estimates at decreasing water activity in natural soils under desiccation. The present study shows that temperature and water activity influence microbial EEA in soils.

Although a Proteobacterium, $P$. aeruginosa, presents optimum values of extracellular enzyme activity under high water content, we have shown that a desiccation-resistant species (i.e., $D$. radiodurans) (Potts, 1994; Slade \& Radman, 2011) helds optimum behavior of its extracellular protease and phosphatase activities under reduced water availability $\left(0.55 \mathrm{a}_{\mathrm{w}}\right)$. On the other hand, D. radiodurans glucosidase activity peaked at $\mathrm{a}_{\mathrm{w}} 1$ which could suggest a different behavior of enzymes targetting polysaccharides versus enzymes related to the $\mathrm{N}$ and $\mathrm{P}$ cycles in this organism.

The behavior of the extracellular enzymes from a thermophilic bacterium (i.e., $P$. thermoglucosidasius) was studied. This is a Firmicutes representative of thermophilic soil bacteria generally detected as viable cells in soils even at temperate and cool zones (Marchant et al., 2002; Portillo et al., 2012; Wong et al., 2015). The extracellular enzymes from $P$. thermoglucosidasius presented singular peaks of maximum activity under low water activity $\left(\mathrm{a}_{\mathrm{w}}\right.$ 0.5-0.8) corresponding to quite dried soils. During hot (and high solar exposition) periods evaporation increases as soil warms up, the water content in soils decreases, then it is reasonable that soil thermophilic bacteria show high activity rates under those extreme temperature and desiccation conditions at upper soil layers. 
388

389

390

391

392

393

394

395

396

397

398

399

400

401

402

403

404

405

406

407

408

409

410

411

412

413

414

415

416

417

418

419

420

421

422

423

424

425

426

427

428

429

430

431

432

433

Previous reports (Grant, 2004; Stevenson et al., 2015) have showed the drastic negative effect that reduced water availability can have on bacterial growth. In fact, the lowest water activity values that are accepted to support bacterial life has been reported at $\mathrm{a}_{\mathrm{w}} 0.75$ for halophilic bacteria (Grant, 2004) and Escherichia coli barely survives at water activity at, or below, 0.95. It has been reported that the lowest limit of water activity that enables cell division is around 0.605 for the xerophilic fungi Xeromyces bisporus (Stevenson et al., 2015). Herein, we have shown that extracellular enzymes (e.g., Deinococcus and Parageobacillus) show activity and function optimally below the limit of water activity for microbial growth.

We also tested whether extracellular enzymes from microbial communities at natural soils also present different behavior depending on their soil environment. We evaluated two soils from different locations, one frequently exposed to heat and dryness (Southern Spain) and the second one rarely exposed to these conditions (Northern Spain). Enzymes from the mesophilic microorganisms, both from the Southern and Northern Spanish soils, showed optimum activities at high water activities $\left(a_{w}>0.95\right)$, the extracellular activity from the thermophilic microbial population $\left(\right.$ at $60^{\circ} \mathrm{C}$ ) at a heat and dryness exposed soil (Southern Spain) presented optimum (maximum) enzymatic activities at reduced water activities $\left(a_{w}, 0.65\right)$. The extracellular enzyme activity from thermophiles at a cool soil (Northern Spain) showed the peak of maximum enzyme activity at high water activity similarly to their mesophilic counterparts. Mesophiles thrive under low temperature conditions, a more permissive scenario to conserve water that the high temperature extremes required by soil thermophilic activity. This study represents a first report suggesting a potential capability of natural microbial communities to adapt to the environmental conditions existing in their niches.

\section{Conclusions}

How extracellular enzymes function in highly heterogeneous particulate media, such as soils, is a topic that requires further investigation. Temperature and water activity are two parameters that show differential and decisive influence on extracellular enzyme activities of soil microbial communities. Our results show that the extracellular enzymes from microorganisms inhabiting, for example, arid and semi-arid soils present relatively high capability to decompose complex organic matter under conditions of water scarcity than previously assumed. These results complement current attempts to understand microbial biogeography by suggesting that bacterial physiology and, likely, distribution can be influenced by environmental factors such as temperature and water content.

\section{Acknowledgements}

This study was supported by funding through projects from the Spanish Ministry of Economy and Competitiveness (CGL2014-58762-P) and the Regional Government of Andalusia (RNM2529 and BIO288). These projects have been cofunded by FEDER funds.

\section{References}

Allison SD, Treseder KK. 2008. Warming and drying suppress microbial activity and carbon cycling in boreal forest soils. Global Change Biology 14:2898-2909 DOI: 10.1111/j.13652486.2008.01716. $\mathrm{x}$

Alster CJ, Weller ZD, von Fischer JC. 2018. A meta-analysis of temperature sensitivity as a microbial trait. Global Change Biology 24:4211-4224 DOI: 10.1111/gcb.14342

Peer] reviewing PDF | (2020:08:52457:3:0:NEW 25 Jan 2021) 
434

435

436

437

438

439

440

441

442

443

444

445

446

447

448

449

450

451

452

453

454

455

456

457

458

459

460

461

462

463

464

465

466

467

468

469

470

471

472

473

474

475

476

477

478

479

480

481

482
Asmar F, Eiland F, Nielsen NE. 1994. Effect of extracellular-enzyme activities on solubilization rate of soil organic nitrogen. Biology and Fertility of Soils 17:32-38 DOI: 10.1007/BF00418669

Biederman J, Scott RL, Goulden ML, et al. 2016. Terrestrial carbon balance in a drier world: the effects of water availability in southwestern North America. Global Change Biology 22:18671879 DOI: 10.1111/gcb.13222

Borowik A, Wyszkowska J. 2016. Soil moisture as a factor affecting the microbiological and biochemical activity of soil. Plant, Soil and Environment 62:250-255 DOI: 10.17221/158/2016-PSE

Bragazza L, Buttler A, Robroek BJM, et al. 2016. Persistent high temperature and low precipitation reduce peat carbon accumulation. Global Change Biology 22:4114-4123 DOI: 10.1111/gcb.13319

Cheng L, Zhang N, Yuan M, et al. 2017. Warming enhances old organic carbon decomposition through altering functional microbial communities. ISME Journal 11:1825-1835 DOI: 10.1038/ismej.2017.48

Chróst RJ. 1992. Significance of bacterial ectoenzymes in aquatic environments. Hydrobiologia, 244, 61-70 DOI: 10.1007/BF00007020

Conant RT, Ryan MG, Ågren GI, et al. 2011. Temperature and soil organic matter decomposition rates - synthesis of current knowledge and a way forward. Global Change Biology 17:33923404 DOI: 10.1111/j.1365-2486.2011.02496.x

Craine J, Spurr R, McLauchlan R, Fierer N. 2010. Landscape-level variation in temperature sensitivity of soil organic carbon decomposition. Soil Biology \& Biochemistry 42:373-375 DOI: 10.1016/j.soilbio.2009.10.024

Davidson EA, Janssens IA. 2006. Temperature sensitivity of soil carbon decomposition and feedbacks to climate change. Nature 440:165-173 DOI: 10.1038/nature04514

Datta R, Anand S, Moulick A, et al. 2017. How enzymes are adsobed on soil phase and factors limiting its activity: A review. International Agrophysics 31:287-302 DOI: 10.1515/intag2016-0049

Duran N, Esposito E. 2000. Potential applications of oxidative enzymes and phenoloxidase-like compounds in wastewater and soil treatment: a review. Applied Catalysis B: Environmental 28:83-99 DOI: 10.1016/S0926-3373(00)00168-5

Gonzalez JM, Portillo MC, Piñeiro-Vidal M. 2015. Latitude-dependent underestimation of microbial extracellular enzyme activity in soils. International Journal of Environmental Science and Technology 12:2427-2434 DOI: 10.1007/s13762-014-0635-7

Intergovernmental Panel on Climate Change (IPCC). 2020. AR5 Synthesis report: Climate Change 2014. https://www.ipcc.ch/report/ar5/syr/. Last visited on August 17th, 2020

Kolman K, Makowski MM, Golriz AA, et al. 2014. Adsorption, aggregation, and desorption of proteins on smectite particles. Langmuir 30:11650-11659 DOI: 10.1021/la502840s

Lee MY, Dordick JS. 2002. Enzyme activation for nonaqueous media. Current Opinion in Biotechnology 13:376-384 DOI: 10.1016/S0958-1669(02)00337-3

Lupatini M, Korthals GW, de Hollander M, et al. 2017. Soil microbiome is more heterogeneous in organic than in conventional farming system. Frontiers in Microbiology 7:2064 DOI: 10.3389/fmicb.2016.02064

Lyer PV, Ananthanarayan L. 2008. Enzyme stability and stabilization - Aqueous and nonaqueous environment. Process Biochemistry 43:1019-1032.

Madigan M, Martinko JM, Parker J. 2003. Brock biology of microorganisms. New Jersey: Prentice Hall, Inc.

Manzoni S, Schimel JP, Porporato A. 2012. Responses of soil microbial communities to water stress: results from a meta-analysis. Ecology 93:930-938 DOI: 10.1890/11-0026.1 
483

484

485

486

487

488

489

490

491

492

493

494

495

496

497

498

499

500

501

502

503

504

505

506

507

508

509

510

511

512

513

514

515

516

517

518

519

520

521

522

523

524

525

526

527

528

529
Marchant R, Banat IM, Rahman TJ, Berzano M. 2002. The frequency and characteristics of highly thermophilic bacteria in cool soil environments. Environmental Microbiology 4:595602 DOI: 10.1046/j.1462-2920.2002.00344.x

Mathlouthi M. 2001. Water content, water activity, water structure and the stability of foodstuffs. Food Control 12: 409-417 DOI: 10.1016/S0956-7135(01)00032-9

McCalley CK, Sparks JP. 2009. Abiotic gas formation drives nitrogen loss from a desert ecosystem. Science 326:837-840 DOI: 10.1126/science.1178984

Meyer KM, Memiaghe H, Korte L, et al. 2018. Why do microbes exhibit weak biogeographic patterns? ISME Journal 12:1404-1413 DOI: 10.1038/s41396-018-0103-3

Moxley E, Puerta-Fernández E, Gómez EJ, Gonzalez JM. 2019. Influence of abiotic factors temperature and water content on bacterial 2-chlorophenol biodegradation in soils. Frontiers in Environmental Sciences 7:41 DOI: 10.3389/fenvs.2019.00041

Portillo MC, Santana M, Gonzalez JM. 2006. Presence and potential role of thermophilic bacteria in temperate terrestrial environments. Naturwissenschaften 99:43-53 DOI: 10.1007/s00114011-0867-z

Fierer N, Colman BP, Schimel JP, Jackson RB. 2006. Predicting the temperature dependence of microbial respiration in soil: a continental-scale analysis. Global Biogeochemical Cycles 20:110 DOI: $10.1029 / 2005 G B 002644$

Grant WD. 2004. Life at low water activity. Philosophical Transactions of the Royal Society of London B Biological Sciences 359:1249-1266 DOI: 10.1098/rstb.2004.1502

Hudson EP, Eppler RK, Clark DS. 2005. Biocatalysis in semi-aqueous and nearly anhydrous conditions. Current Opinion in Biotechnology 16:637-643 DOI: 10.1016/j.copbio.2005.10.004

Maurice S, Coroller L, Debaets S, et al. 2011. Modeling the effect of temperature, water activity and $\mathrm{pH}$ on the growth of Serpula lacrymans. Journal of Applied Microbiology 111:1436-1446 DOI: $10.1111 / \mathrm{j} .1365-2672.2011 .05161 . \mathrm{x}$

Oren A. 2010. Thermodynamic limits to microbial life at high salt concentrations. Environmental Microbiology 13:1908-1923 DOI: 10.1111/j.1462-2920.2010.02365.x

Potts M. 1994. Desiccation tolerance of prokaryotes. Microbiology \& Molecular Biology Reviews 58:755-805

Rodrigues RC, Ortiz C, Berenguer-Murcia A, Torres R, Fernández-Lafuente R. 2013. Modifying enzyme activity and selectivity by immobilization. Chemical Society Reviews 42:6290-6307 DOI: $10.1039 / \mathrm{c} 2 \mathrm{cs} 35231 \mathrm{a}$

Santana MM, Gonzalez JM. 2015. High temperature microbial activity in upper soil layers. FEMS Microbiology Letters 362:1-4 DOI: 10.1093/femsle/fnv182

Slade D, Radman M. 2011. Oxidative stress resistance in Deinococcus radiodurans. Microbiology \& Molecular Biology Reviews 75:133-191 DOI: 10.1128/MMBR.00015-10

Soares CM, Teixeira VH, Baptista AM. 2003. Protein structure and dynamics in nonaqueous solvents: insights from molecular dynamics simulation studies. Biophysical Journal 84:16281641.Sokal RR, Rohlf FJ. 2012. Biometry, Fourth ed. New York: WH Freeman \& Co.

Stark JM, Firestone MK. 1995. Mechanisms of soil moisture effects on activity of nitrifying bacteria. Applied and Environmental Microbiology 61:218-221 DOI: 10.1128/AEM.61.1.218221.1995

Steinweg JM, Dukes JS, Wallenstein MD. 2012. Modeling the effects of temperature and moisture on soil enzyme activity: Linking laboratory assays to continuous field data. Soil Biology \& Biochemistry 55:85-92 DOI: 10.1016/j.soilbio.2012.06.015

Stemmer M. 2004. Multiple-substrate enzyme assays: a useful approach for profiling enzyme activity in soils?. Soil Biology \& Biochemistry 36:519-527 DOI: 10.1016/j.soilbio.2003.11.004 
530

531

532

533

534

535

536

537

538

539

540

541

542

543

544

545

546

547

548

549

550

551

552

553

554

555

556

557
Stevenson A, Burkhardt J, Cockell CS, et al. 2015. Multiplication of microbes below 0.690 water activity: implications for terrestrial and extraterrestrial life. Environmental Microbiology 17:257-277 DOI: 10.1111/1462-2920.12598

Tecon R, Or D. 2017. Biophysical processes supporting the diversity of microbial life in soil. FEMS Microbiology Reviews 41:599-623 DOI: 10.1093/femsre/fux039

Torres S, Castro G. 2004. Non-aqueous biocatalysis in homogeneous solvent systems. Food Technology and Biotechnology 42:271-277.

Townsend A, Vitousek PM, Holland EA. 1992. Tropical soils could dominate the short-term carbon cycle feedbacks to increased global temperatures. Climate Change 22:293-303 DOI: 10.1007/BF00142430

Valaskova V, Baldrian P. 2005. Estimation of bound and free fractions of lignocellulosedegrading enzymes of wood-rotting fungi Pleurotus ostreatus, Treametes versicolor and Piptoporus betulinus. Research in Microbiology 157:119-124 DOI: 10.1016/j.resmic.2005.06.004

Velasco-Ayuso S, Guerrero MC, Montes C, López-Archilla AI. 2011. Regulation and Spatiotemporal Patterns of Extracellular Enzyme Activities in Coastal, Sandy Aquifer Systemn (Doñana, SW Spain). Microbial Ecology 62:162-176 DOI: 10.2307/41489772

Vos M, Wolf AB, Jennings SJ, Kowalchuk GA. 2013. Micro-scale determinants of bacterial diversity in soil. FEMS Microbiology Reviews 37:936-954 DOI: 10.1111/1574-6976.12023

Wallenstein MD, Weintraub MN. 2008. Emerging tools for measuring and modeling the in situ activity of soil extracellular enzymes. Soil Biology \& Biochemistry 40:2098-2106 DOI: 10.1016/j.soilbio.2008.01.024

Whitman WB, Coleman DC, Wiebe WJ. 1998. Prokaryotes: the unseen majority. Proceedings of the National Academy of Science USA 956578-6583 DOI: 10.1073/pnas.95.12.6578

Wong M-L, An D, Caffrey SM, Soh J, et al. 2015. Roles of thermophiles and fungi in bitumen degradation in mostly cold oil sands outcrops. Applied and Environmental Microbiology 81:6825-6838 DOI: 10.1128/AEM.02221-15 
Figure 1

Figure 1. Comparative scheme of the standard, in-solution assay (A) and the newly proposed, soil-based assay (B) used in this study.

Figure 1. Comparative scheme of the standard, in-solution assay (A) and the newly proposed, soil-based assay (B) used in this study. Note that the same protocol applies to both assays with the exception of the additional steps required in B. A diamond indicates a step where a reagent solution is added; the rectangle indicates other steps. 


\section{A Standard, solution assay}

New, solid assay B (additional steps)

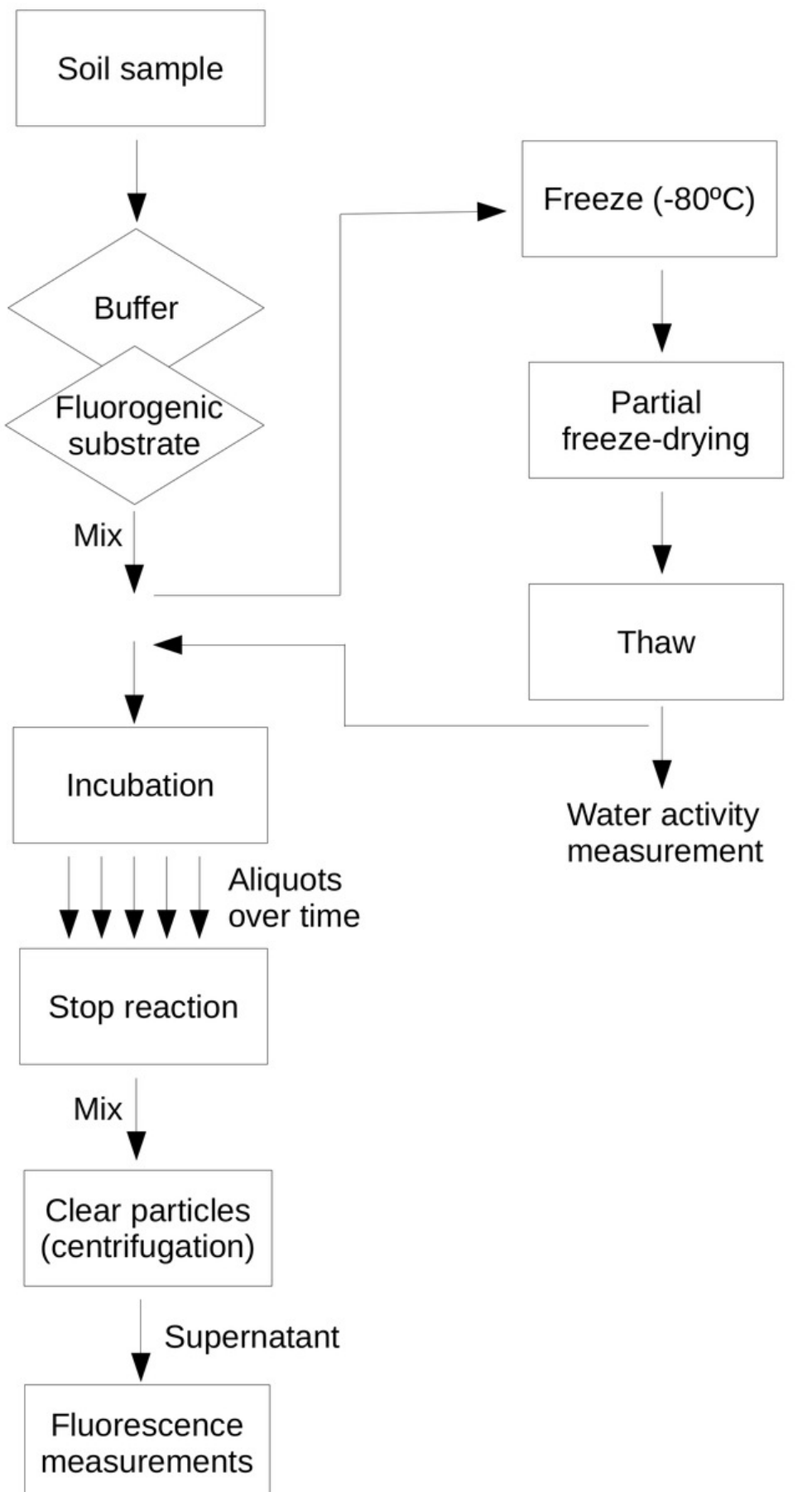




\section{Figure 2}

Figure 2. Examples of the activity rate versus substrate concentration at water activity 0.95 using the proposed soil-based assay on a South Spain soil.

Figure 2. Examples of the activity rate (i.e., fluorescence increase over time) versus substrate concentration at water activity 0.95 using the proposed soil-based assay on the South Spain soil. The results of this method showed a Michaelis-Menten kinetics. Grey square, phosphatase activity; black triangle, protease activity; grey diamond, glucosidase activity. 


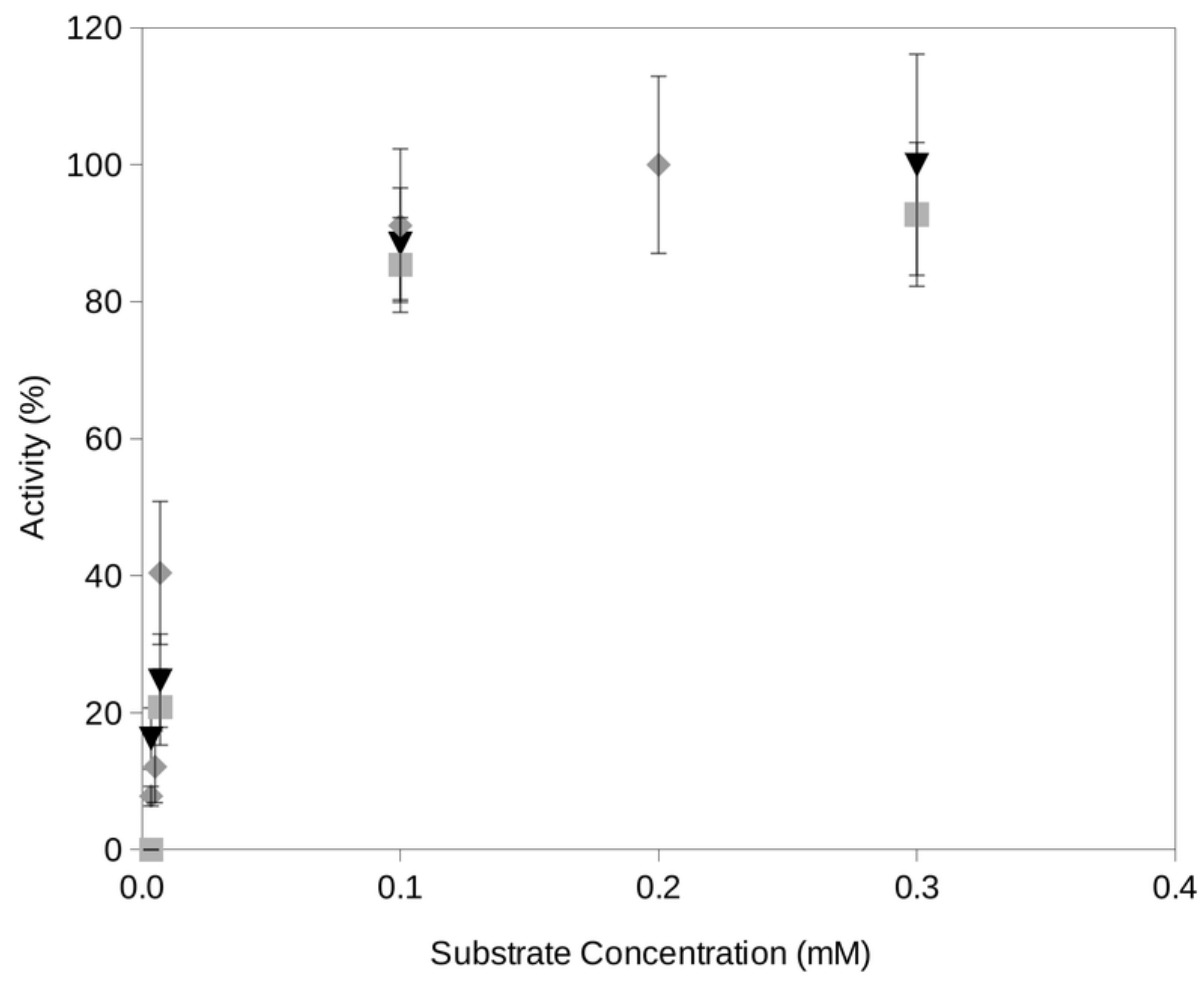

Peer) reviewing PDF | (2020:08:52457:3:0:NEW 25 Jan 2021) 


\section{Figure 3}

Figure 3. Comparison of the results obtained using the standard enzyme activity assay (in-solution assay) and the proposed soil-supported activity method at the same substrate concentration, temperature and water activity $\left(a_{w}=1\right)$ conditions.

Figure 3. Comparison of the results obtained using the standard enzyme activity assay (insolution assay) and the proposed soil-supported activity method at the same substrate concentration, temperature and water activity $\left(a_{w}=1\right)$ conditions. Reactions at $20^{\circ} \mathrm{C}$ and $60^{\circ} \mathrm{C}$ were performed to estimate protease, phosphatase and glucosidase activities in two natural soil samples, a sandy loam (Southern Spain) and a silt (Northern Spain) soil. Correlation coefficient between these data was $0.90(n=12 ; P<0.001)$. The dashed straight line indicates the 1:1 correspondence as a reference. Axes are in logarithmic scale. RFU, Relative Fluorescent Units. 


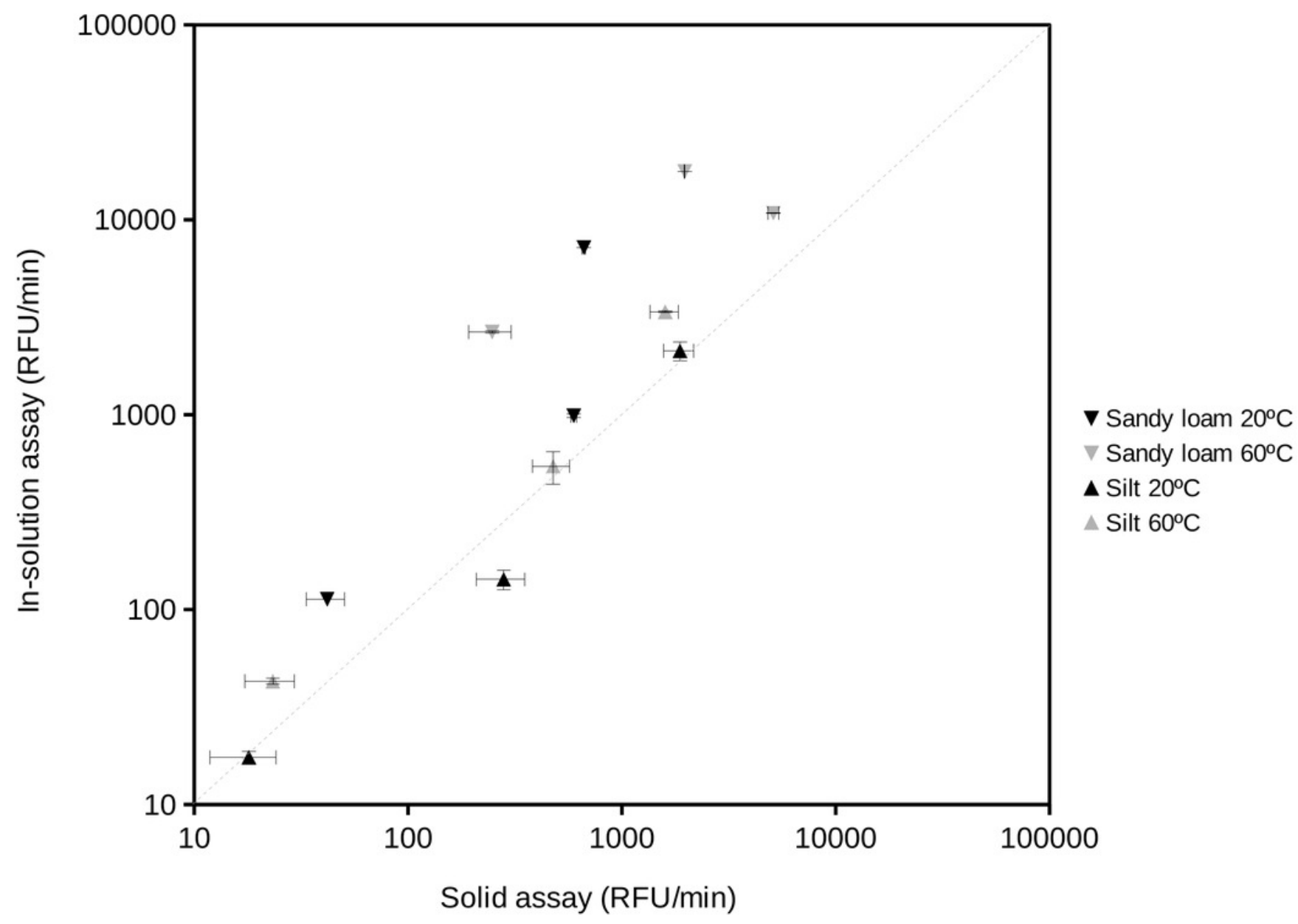




\section{Figure 4}

Figure 4. Relative extracellular enzyme activity as a function of water activity $\left(a_{w}\right)$ for three bacterial species

Figure 4. Relative extracellular enzyme activity as a function of water activity $\left(a_{w}\right)$ for three bacterial species: Pseudomonas aeruginosa (35우 $\mathrm{A})$, Deinococcus radiodurans (28윽 B), and Parageobacillus thermoglucosidasius ( $\left.60^{\circ} \mathrm{C} ; \mathrm{C}\right)$. Three different extracellular activities were tested: glucosidase (blue triangles), phosphatase (red squares) and protease (green diamonds) activities. Error bars represent one standard deviation. Results are shown as percentages of the maximum activity rate. 

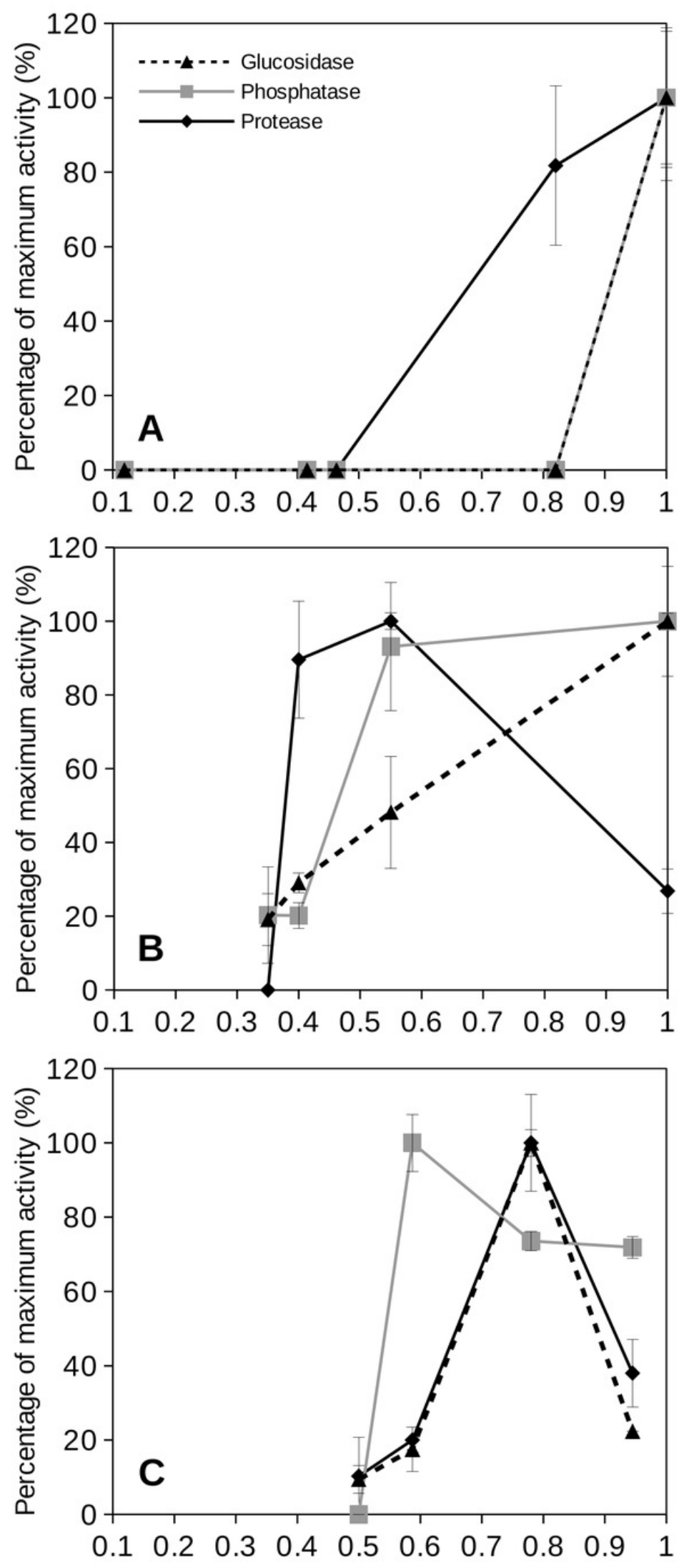

Water activity 
Figure 5

Figure 5. Extracellular enzyme activities at different temperatures as a function of water activity for two distinctive soils

Figure 5. Extracellular enzyme glucosidase ( $A$ and $C)$ and protease ( $B$ and $D)$ activities at different temperatures $\left(20^{\circ} \mathrm{C}\right.$, blue triangles, and $60^{\circ} \mathrm{C}$, red squares) as a function of water activity $\left(a_{w}\right)$ for two distinctive soils, one frequently exposed to heat and dryness (Southern Spain; A and B), and the second one from a wet and moderate temperature soil (Northern Spain; $C$ and D). Error bars represent one standard deviation.
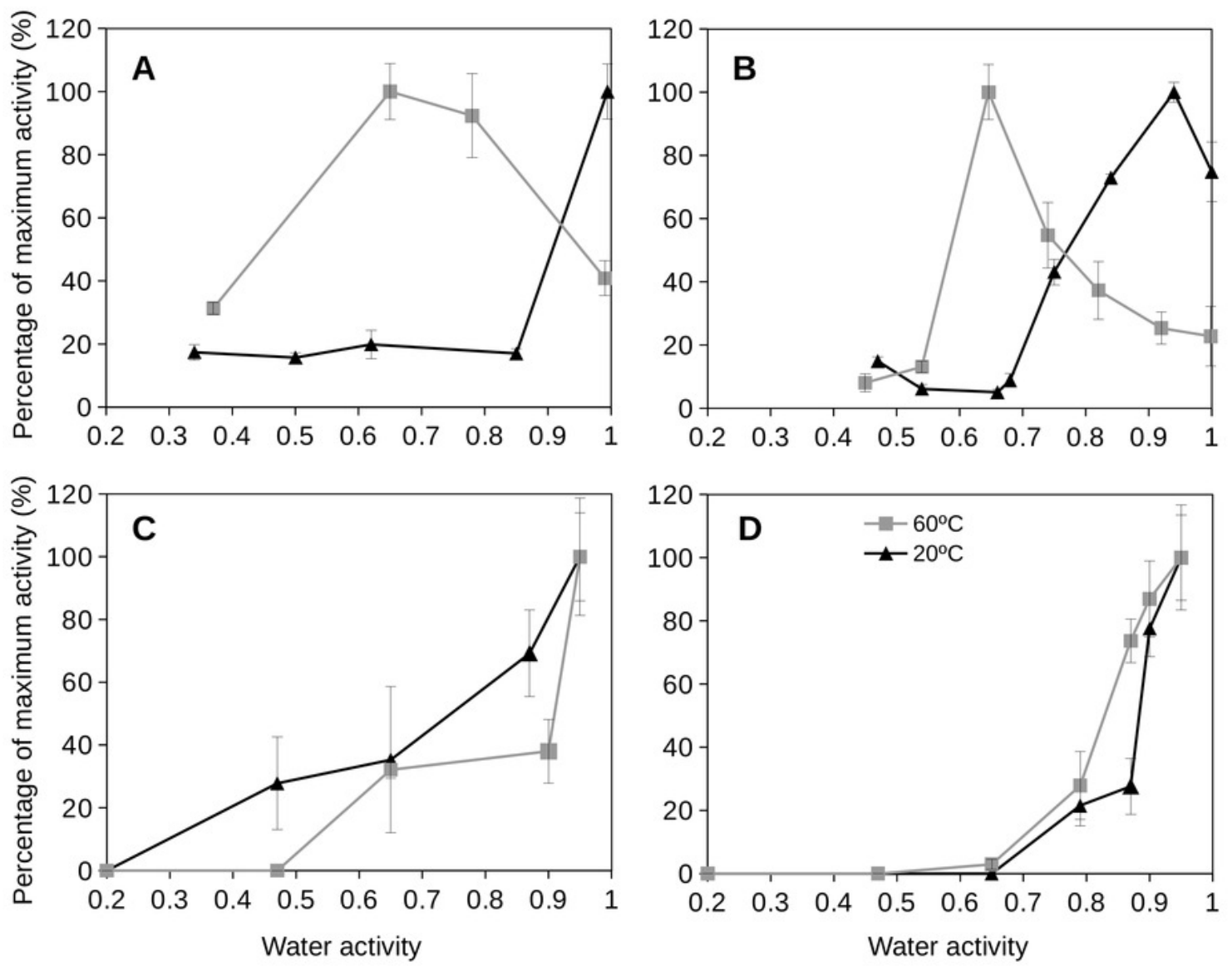


\section{Table $\mathbf{1}$ (on next page)}

Table 1. Properties for the bacterial species used in this study

Table 1. Properties for the bacterial species used in this study 
Table 1. Properties for the bacterial species used in this study

\begin{tabular}{lccccc}
\hline $\begin{array}{l}\text { Species } \\
\text { Strain }\end{array}$ & $\begin{array}{l}\text { Accession } \\
\text { No. }\end{array}$ & $\begin{array}{l}\text { Optimum Growth } \\
\text { temperature }\end{array}$ & $\begin{array}{l}\text { Classification } \\
\text { by temperature }\end{array}$ & Phylum \\
\hline $\begin{array}{l}\text { Pseudomonas } \\
\text { aeruginosa }\end{array}$ & PAO1 & CECT 4122 & $35^{\circ} \mathrm{C}$ & Mesophile & Proteobacteria \\
\hline $\begin{array}{l}\text { Deinococcus } \\
\text { radiodurans }\end{array}$ & R1 & CECT 833 & $28^{\circ} \mathrm{C}$ & Mesophile & Deinococcus/ \\
\hline $\begin{array}{l}\text { Parageobacillus } \\
\text { thermoglucosidasius }\end{array}$ & 23.6 & CECT 9776 & $60^{\circ} \mathrm{C}$ & Thermophile & Firmicutes \\
\hline
\end{tabular}

${ }^{1}$ CECT, Colección Española de Cultivos Tipo, Spanish Type Culture Collection 


\section{Table 2 (on next page)}

Table 2. Some characteristics of the two natural soils analyzed in this study.

Table 2. Some characteristics of the two natural soils analyzed in this study. 
Table 2. Some characteristics of the two natural soils analyzed in this study.

\begin{tabular}{|c|c|c|c|c|c|c|c|c|c|}
\hline Location & Municipality & Coordenates & $\begin{array}{c}\text { Temperature } \\
\text { (annual mean; } \\
{ }^{\circ} \mathrm{C} \text { ) }\end{array}$ & $\begin{array}{c}\text { Precipitation } \\
\text { (annual mean; } \\
\text { mm) }\end{array}$ & $\begin{array}{c}\text { Climate } \\
\text { type }^{1}\end{array}$ & $\begin{array}{l}\text { Soil } \\
\text { type }\end{array}$ & $\begin{array}{c}\text { Sand/Silt/Clay } \\
\text { content }(\%)\end{array}$ & $\mathbf{p H}$ & $\begin{array}{c}\text { Organic } \\
\text { Matter } \\
(\%)\end{array}$ \\
\hline Southern & Coria del & $\mathrm{N} 37^{\circ} 17.027^{\prime}$ & 18.4 & 572 & Csa & Sandy & $69.4 / 27.8 / 2.8$ & 7.4 & 7.0 \\
\hline Spain & Rio, Sevilla & $\mathrm{W} 006^{\circ} 3.973^{\prime}$ & & & & loam & & & \\
\hline Northern & Benasque, & $\mathrm{N} 42^{\circ} 40.922^{\prime}$ & 8.2 & 1013 & $\mathrm{Cfb}$ & Silt & $12.6 / 83.3 / 4.1$ & 6.5 & 12.2 \\
\hline \multirow[t]{2}{*}{ Spain } & Huesca & $\mathrm{E} 000^{\circ}$ & & & & & & & \\
\hline & & 38.108 & & & & & & & \\
\hline
\end{tabular}

${ }^{1}$ Köppen-Geiger climate classification. 